\title{
Inherited Disorders of Transition Metal Metabolism: An Update
}

Peter T. Clayton

Centre for Translational Omics, Genetics and Genomic Medicine, UCL Great Ormond Street Institute of Child Health, 30 Guilford Street, London WC1N 1EH, UK. 


\section{Abstract}

Elements with a biological role include six trace transition metals: manganese, iron, cobalt, copper, zinc and molybdenum. Transition metals participate in group transfer reactions such as glycosylation and phosphorylation and those that can transfer an electron by alternating between two redox states such as iron $(3+/ 2+)$ and copper $(2+/ 1+)$ are also very important in biological redox reactions including the reduction of molecular oxygen and the transport of oxygen. However, these trace metals are also potentially toxic, generating reactive oxygen species through Fenton chemistry. Recently, a role of trace metals in host defence ("nutritional immunity") has been recognized. The host can deprive the pathogen of a trace metal or poison it with a toxic concentration.

Disorders leading to low concentrations of a trace metal can often be treated by supplementing that metal; disorders leading to excessively high concentrations can often be treated with chelating agents such as penicillamine and disodium calcium edetate.

This update will address: i) the manganese / zinc transporters (because two new treatable disorders were described in 2016 - SLC39A8 deficiency and SLC39A14 deficiency); ii) copper transporter disorders because we need to improve the treatment of patients with neurological symptoms due to Wilson's disease; and iii) iron homeostasis because recent progress in research into the metabolism of iron and its regulation helps us better understand several inborn errors affecting these pathways. 
All studies in the author's centre were conducted with ethical approval and signed consent from subjects / parents.

Peter Clayton declares he has no conflict of interest with regard to information presented in this review. He does receive consultation fees from Actelion.

No identifying information about patients is included in the article.

All institutional and national guidelines for the care and use of laboratory animals were followed. 


\section{Introduction}

To many scientists, the "transitional elements" or "transitional metals" are those in the d series (sometimes referred to as Groups 3 to 12) of the periodic table (Figure 1). Using this definition, there are six transition metals with biological activity: manganese, iron, cobalt, copper, zinc and molybdenum. [Selenium is often included in reviews of trace metals but is actually a non-metal with properties more like those of the element above it in Group 16, sulphur.] The IUPAC definition defines a transition metal as "an element whose atom has a partially filled $d$ sub-shell, or which can give rise to cations with an incomplete $d$ sub-shell" (IUPAC 2006). This excludes zinc which has a complete $d$ sub-shell.

\section{Biological Redox Reactions}

The importance of an incomplete $d$ sub shell is that electrons in this orbital can participate in bonding (alongside the $4 \mathrm{~s}$ electrons) so that the element can exist in different oxidation states eg. $3+/ 2+(\mathrm{Fe})$ or $2+/ 1+(\mathrm{Cu})$. This confers on manganese, iron, cobalt, copper and molybdenum, the ability to participate in redox reactions by switching between redox states. This is important for copper and iron in the reduction of molecular oxygen in complex IV of the respiratory chain (Sharma, Karlin \& Wikström 2013) and for iron in transport of oxygen by haemoglobin.

\section{Group Transfer Reactions}

Transitional metals (including zinc) can also participate in group transfer reactions e.g transfer of a phosphate residue (phosphorylation or dephosphorylation) or transfer of a sugar residue (glycosylation). For example, when the enzyme $\beta$-1,4-galactosyltransferase is transferring a galactose residue from UDP-galactose to glucose, the developing negative 
charge on UDP needs to be neutralized by a divalent cation and $\mathrm{Mn}^{2+}$ is the most efficient cation (Ramakrishnan, Ramasamy \& Qasba 2006). Hence deficiency of manganese leads to impaired activity of $\beta$-1,4-galactosyltransferase.

\section{Toxicity (Fenton Chemistry)}

Although essential for biological catalysis as indicated above, the transition metals are also potentially highly toxic. One mechanism for toxicity arises through the ability to switch redox states in non-enzyme catalyzed reactions, in particular through Fenton chemistry. The best known example is the reaction between ferrous $\left(\mathrm{Fe}^{2+}\right)$ ions and hydrogen peroxide to produce the highly reactive hydroxyl and hydroperoxyl radicals:

(1) $\mathrm{Fe}^{2+}+\mathrm{H}_{2} \mathrm{O}_{2} \rightarrow \mathrm{Fe}^{3+}+\mathrm{HO}^{\bullet}+\mathrm{OH}^{-}$

(2) $\mathrm{Fe}^{3+}+\mathrm{H}_{2} \mathrm{O}_{2} \rightarrow \mathrm{Fe}^{2+}+\mathrm{HOO}^{\bullet}+\mathrm{H}^{+}$

The hydroxyl and hydroperoxyl radicals ("reactive oxygen species", ROS) can oxidise lipids, protein and DNA leading to serious damage to the cell.

\section{Neurotoxicity}

Accumulation of copper, manganese and iron in the brain leads to neuronal damage. The basal ganglia and substantia nigra are particularly vulnerable. In Wilson's disease, a movement disorder is common; the same is true of the two disorders that lead to high blood manganese levels (SLC30A10 and SLC39A14 deficiency). In haemochromatosis, however, neurological disease is rare (Niederau et al. 1996). The link between systemic iron overload and the accumulation of iron in the brain that has been implicated in Parkinson's disease and Alzheimer's disease is clearly complex (Zecca et al. 2004). For example a study of common haemochromatosis mutations in familial Alzheimer's disease showed that they 
were overrepresented in males and underrepresented in females (Moalem et al. 2000).

Equally puzzling is the fact that there are 10 inborn errors that do lead to

neurodegeneration with brain iron accumulation (NBIA) (van Hasselt et al 2016), however, the link between the primary genetic defect and the iron accumulation in the basal ganglia and substantia nigra is only clear for two (acaeruloplasminemia and neuroferritinopathy, discussed below). Disorders leading to accumulation of transition metals in the basal ganglia are summarized in Table 1.

\section{Transition Metals in Host Defence}

Transition metals are essential but toxic for microorganisms as well as for man. This fact is used by the immune system; the host can deprive the pathogen of a trace metal or poison it with a toxic concentration; this is referred to as "nutritional immunity", part of the innate immune system. Thus an iron transporter SLC11A1 can control intracellular microbial replication by removing $\mathrm{Fe}^{2+}$ and other essential divalent cations from the phagosome (see below and Canonne-Hergauxet al 1999).

\section{Treatment of Transition Metal Disorders}

Several of the transition metal disorders can be treated very effectively. Deficiency of a metal can often be made good by oral supplementation. Treatment of metal toxicity can be achieved by the use of a second metal that competes for uptake / transport e.g. iron which competes with manganese for intestinal uptake (by DMT1) and for transport and cellular uptake (transferrin/transferrin receptor) can be used in the treatment of a disorder in which manganese accumulates (Tuschl et al 2008). An alternative treatment for toxicity is removal 
of the offending transition metal by chelation therapy. Chelation of copper with agents such as penicillamine and trientine is well established. Other more powerful chelating agents for copper will be discussed below. Intravenous infusion of disodium calcium edetate has proved valuable in the treatment of manganese toxicity disorders (Tuschl et al 2008, 2012, 2016). This chelator has been used frequently for the treatment of lead poisoning. When considering whether a chelator is likely to be effective, two factors should be taken into account: Firstly, the stability constant; disodium calcium edetate will chelate those metals that bind with a higher stability constant than calcium ( $\mathrm{Mn}, \mathrm{Fe}, \mathrm{Co}, \mathrm{Zn}, \mathrm{Cd}, \mathrm{Pb}, \mathrm{Ni}$ ). Secondly, whether the accumulating metal is free or bound; disodium calcium edetate will bind unbound metal ions much more effectively than bound (e.g. for manganese, the plasma fraction that is not bound to transferrin). Toxicity of iron can be treated by removal of iron either by venesection or by chelators such as deferoxamine or deferiprone.

This review will concentrate on three areas: i) manganese / zinc transporters (because two new disorders were described in 2015/2016 and because these have led us to reconsider the major role(s) of some transporters; ii) disorders of copper transport leading to copper toxicity (because treatment of Wilson's disease is sometimes unsatisfactory and because there are some new potential treatments); iii) disorders of iron homeostasis because iron is the transition metal for which we have the most complete understanding of routes of metabolism and their regulation.

\section{Zinc/ManganeseTransporters}

\section{Cell Surface Transporters}

A recent review of zinc transporters suggested that several members the SLC39A family (ZIP transporters; 1-6, 8-10, 12 \&14) mainly mediate uptake of zinc at the cell surface, although 
some can also transport iron manganese and cadmium, and that SLC39A4 (ZIP4), SLC39A8 (ZIP8) and SLC39A14 (ZIP14) all had similar functions as shown in Figure 2 (Kambe et al. 2015). A recent review of manganese transporters similarly suggested that SLC39A8 and SLC39A14 have similar functions mediating manganese uptake at the cell surface as shown in Figure 3 (Chen et al. 2015). However, deficiencies of these 3 manganese/zinc transporters cause very different diseases in man: SLC39A4 causes a zinc deficiency disorder (acrodermatitis enteropathica) (Küry et al. 2002); SLC39A8 deficiency mainly causes problems due to cellular manganese deficiency (Boycott et al. 2016, Park et al. 2016) and SLC39A14 is probably mainly a disorder of hepatic uptake (and hence biliary excretion) of manganese leading to symptoms caused by excessively high manganese levels in the brain (Tuschl et al 2016).

Other transporters identified as causing diseases in man when mutated The SLC30A (ZnT) transporters are involved in export of zinc and/or manganese from cells. SLC30A2 (ZnT2) transports zinc into secretory vesicles in mammary epithelial cells; heterozygous mutations in SLC3OA2 in a mother leads to zinc deficiency in her breast-fed infant (Chowanadisa Lönnerdal \& Kelleher 2006). Homozygous SLC30A10 mutations lead to high levels of manganese in liver, blood and brain; the transporter is involved in biliary excretion of manganese (Tuschl et al 2012).

\section{Iron/ Manganese Transporters}

Iron homeostasis will be discussed below but it is important to note that several iron transporters also transport manganese. These include DMT-1 (intestinal and cellular 
uptake); transferrin and the transferrin receptor (transport in blood and cellular uptake) and ferroportin (cellular excretion).

\section{Disorders mainly Affecting Zinc Levels}

\section{SLC39A4 (ZIP4) deficiency. Acrodermatitis enteropathica}

Acrodermatitis enteropathica typically presents in infancy with peri-orificial and acral dermatitis, diarrhoea, recurrent infections, and growth delay. Children may also have mood changes e.g apathy, irritability. This disorder can be treated very effectively with zinc supplementation typically $35-90$ mg elemental zinc per day as the sulphate.

\section{SLC30A2 (ZnT2) deficiency. Breast milk zinc deficiency}

A breast-feeding mother who has a heterozygous mutation in SLC30A2 does not supply enough zinc to her infant in her breast milk and the infant develops symptoms similar to those of acrodermatitis enteropathica (Chowanadisai, Lönnerdal \& Kelleher, 2006). The baby can be treated with a physiological zinc supplement.

\section{Disorders mainly Affecting Manganese Levels}

\section{SLC30A10 (Znt10) Deficiency. Dystonia/Parkinsonism, Hypermanganesaemia,} Polycythaemia, and Chronic Liver Disease

In 2008, we described a syndrome of hepatic cirrhosis, dystonia, polycythaemia and hypermanganesaemia (Tuschl et al. 2008). The T1-weighted MRI scan of the brain showed marked hyperintensity of the basal ganglia - attributable to the accumulation of manganese. Manganese levels in the blood could be reduced by chelation with intravenous disodium calcium edetate and oral iron supplementation and this treatment led to an improvement in the dystonia, the brain MRI appearances and the liver manganese content 
and histology. In 2012, we and others were able to show that this syndrome was caused by mutations in SLC30A10 (Tuschl et al. 2012, Quadri et al. 2012); some of the patients described by Quadri et al had adult onset Parkinsonism rather than childhood onset dystonia.

\section{SLC39A14 (ZIP14 Deficiency). Infantile / Early Childhood onset Dystonia with Hypermanganesaemia}

We discovered that some children with a movement disorder, T1-hyperintensity of the basal ganglia and white matter and hypermanganesaemia did not have mutations in SLC30A10; rather whole exome sequencing revealed mutations in SLC39A14. In 2015, we realized that the group of Manju Kurian working in our institute had found mutations in the same gene in a cohort of children with a movement disorder and T2-hypointensity of the globus pallidus (similar to neurodegeneratioin with brain iron accumulation; NBIA). Fortunately we agreed to collaborate rather than compete and this led to a full description of SLC39A14 deficiency in 8 patients from 5 families (Tuschl et al 2016). This disorder presents in infancy or early childhood with loss of developmental milestones, progressive dystonia and bulbar dysfunction. By 8-10 years, patients typically have generalized, drug-resistant dystonia, spasticity, limb contractures, scoliosis, and loss of independent ambulation but with preserved cognition. Some have additional features of Parkinson's disease (hypomimia, tremor and bradykinesia). They have high blood manganese but (in contrast to SLC30A10 deficiency) no polycythaemia and no liver disease. T1-weighted MRI scans show hyperintensity of the globus pallidus, striatum, cerebral white matter, pituitary, dorsal pons and cerebellum. The liver T1 intensity is not increased (in contrast to SLC30A10 deficiency). SLC39A14 deficiency, like SLC30A10 deficiency responds to treatment with disodium calcium 
edetate, at least if treatment is started before the disease is advanced; the urinary manganese excretion increases markedly, blood manganese falls and the motor impairment improves significantly.

A zebrafish model of SLC39A14 deficiency shows marked accumulation of manganese (and no other metals) in the brain, associated with reduced locomotor activity. The main defect thus appears to be uptake of managesese into the liver which normally allows blood levels of manganese to be reduced by biliary excretion.

\section{SLC39A8 (ZIP8) Deficiency. Hypomanganesaemia, developmental delay plus}

Two papers published simultaneously in 2015 describe the effects of SLC39A8 mutations (Boycott et al. 2015; Park et al 2015, 2016). Boycott et al described 6 patients from the Hutterite community and an Egyptian sibling pair with recessively inherited, developmental delay / intellectual disability, hypotonia, strabismus, and variable short stature. MRI scans showed cerebellar atrophy. Concentrations of manganese and zinc were variably reduced in plasma and increased in urine. They all had a homozygous mutation (p.Gly38Arg) in

SLC39A8. The patient described by Park et al. presented with cranial asymmetry, disproportionate (short-limbed) dwarfism, severe infantile spasms with hypsarrhythmia, hearing loss, and severe developmental delay. The blood manganese was below the limit of detection. The patient's plasma showed an abnormal transferrin glycosylation profile (Type II pattern); this was consistent with reduced activity of a manganese-dependent enzyme required for $\mathrm{N}$-glycosylation - $\beta 1$,4-galalctosyl transferase.

A third patient with mutations in SLC39A8 (homozygous p.Cys113Ser) was described at the symposium and subsequently published in the JIMD (Riley et al 2016/2017) This patient presented with Leigh disease and was confirmed to have a raised CSF lactate and reduced 
activities of complexes II / III and IV in liver. However, a similarly affected sibling also had a type II abnormal transferrin pattern and blood and urine manganese levels were undetectably low. Interestingly the brain imaging findings were opposite to those seen in the disorders in which manganese accumulates (SLC30A10 and SLC39A14 deficiencies); the basal ganglia were hypointense on T1-weighted images and hyperintense on T2. (Since high levels of manganese produce hyperintensity on $\mathrm{T} 1$ and hypointensity on $\mathrm{T} 2$, it seems quite possible that the signal changes in SLC39A8 deficiency are due to low manganese levels). The abnormal transferrin pattern was attributed to reduced $\beta 1,4$-galalctosyl transferase activity and the mitochondrial damage to build up of reactive oxygen species as a result of reduced activity of manganese-dependent superoxide dismutase.

Treatment of SLC39A8 deficiency with an oral galactose supplement corrected the abnormal transferrin pattern (Park et al 2015). Added manganese supplementation led to further clinical improvement with cessation of seizures (Park et al 2016).

\section{Disorders of Copper Homeostasis}

The main effects of mutations in ATP7A are failure of copper uptake by the enterocytes and by the nervous system resulting in cellular copper deficiency and 3 main phenotypes: Menke's disease, occipital horn syndrome and X-linked distal neuropathy (van Hasselt, Clayton \& Houwen, 2016). In contrast, mutations in ATP7B lead to a failure of copper excretion by hepatocytes leading to copper toxicity principally affecting the central nervous system and liver (Wilson's disease). The ATP7A and ATP7B proteins are synthesized in the endoplasmic reticulum, and are then trafficked to the trans-Golgi network and on to the basolateral plasma membrane (ATP7A) or the apical (canalicular) plasma membrane 
(ATP7B). This update will focus on challenges in the treatment of Wilson's disease and potential new approaches and describe some conditions in which the trafficking of ATP7B and or ATP7A from ER through trans-Golgi to plasma membrane is defective.

\section{i) Challenges and New Approaches in the Treatment of Wilson's Disease.}

\section{Neurological Presentation}

Patients with Wilson's disease who present with neurological symptoms typically present between the ages of 8 and 20 years and most often with a movement disorder, particularly dysarthria and dysgraphia, progressing to tremor, dystonic rigidity and drooling. In a subgroup, psychiatric symptoms predominate ranging from impulsivity and irritability to frank psychosis. T2-weighted MRI images typically show changes in the striatum but individual patients show marked heterogeneity in the striatal changes in terms of the location and density of both hyperintense and hypointense signals (Schlaug et al. 1996). The neurological symptoms of Wilson's disease can be very debilitating so it is a tragedy when they get worse when the paediatrician / physician is trying to treat the patient in a way that will lead to improvement in these symptoms. This is particularly so in the $34 \%$ of cases in which the neurological deterioration is irreversible. A recent study confirmed that worsening of neurological symptoms can occurr in $35 \%$ of patients treated with Dpenicillamine $(n=35)$ and $19 \%$ of patients treated with zinc sulphate $(n=21)$ a difference that was not statistically significant (Czlonkowska et al 2014, Litwin et al. 2015). On the other hand, a study in 2006 by Brewer et al. showed that neurological deterioration on treatment occurred in $27 \%$ of patients treated with trientine $(n=23)$ but only in $4 \%$ of patients treated with ammonium tetrathiomolybdate $(n=25)$, a difference that was significant at the $p<0.05$ 
level. Tetrathiomolybdate has been awarded Orphan Drug status in Europe. Clearly further studies are required to find the optimum treatment for neurological Wilson's disease.

\section{Liver Failure}

Liver failure in Wilson's disease is currently treated by liver transplantation; a patient with a severity score of 11 is unlikely to survive with chelation therapy (Dhawan et al. 2005). However, liver transplantation is limited by the availability of donor organs / segments, so a new approach to liver failure being tested in an animal model of Wilson's disease, is of considerable interest. Lichtmannegger et al. (2016) showed that methanobactin could reverse acute liver failure in the ATP7B-deficient rat. Methanobactin is a peptide produced by Methylosinus trichosporium OB3b that has an exceptionally high affinity for copper and it was shown to be more efficient than D-penicillamine, trientine, and tetrathiomolybdate in extracting copper from liver mitochondria of Atp $7 \mathrm{~b}^{-/-}$rats. The rats have hepatic copper accumulation, liver damage and mitochondrial impairment. Short term treatment with methanobactin reversed mitochondrial impairment and liver damage and prevented liver failure and death in the rats, providing a rationale for clinical trials in man.

\section{ATP7B Proteins Retained in the Endoplasmic Reticulum}

Several ATP7B mutations, including the common mutations, $\mathrm{H} 1069 \mathrm{Q}$ and $\mathrm{R} 778 \mathrm{~L}$, produce proteins that are active but are retained in the endoplasmic reticulum whereas they need to travel to the cell surface to bring about copper excretion. In addition, expression of $\mathrm{H} 1069 \mathrm{Q}$ activates p38 and c-Jun N-terminal kinase (JNK) signaling pathways and this leads to rapid degradation of the mutant protein. Chesi et al (2016) have shown that suppression of p38 and c-Jun pathways with small inhibitory RNA (siRNA) or chemical inhibitors allows the protein to get to the trans-Golgi network, leading to restoration of copper-dependent 
trafficking and reduction of cellular copper levels. These findings suggest that there may, in the future, be additional treatments for patients with Wilson's disease who harbour mutations causing retention of the protein in the ER.

\section{ii) ATP7A and ATP7B Retained in the Trans-Golgi Network-MEDNIK syndrome}

Martinelli, Dionisi Vici and colleagues have recently described a disorder that combines features of Wilson's disease and Menke's disease and is caused by defective trafficking of ATP7A and ATP7B proteins from the trans-Golgi network (TGN) to the cell membrane and other organelles (Martinelli et al. 2013; Martinelli and Dionisi-Vici 2014). MEDNIK syndrome is characterized by mental retardation, enteropathy, deafness, peripheral neuropathy ichthyosis and keratoderma plus brain atrophy and cholestatic hepatopathy. Copper and caeruloplasmin concetrations are reduced in plasma and liver copper is elevated. Like Wilson's disease, the disorder responds to treatment with zinc acetate. The underlying cause is mutations in AP1S1, encoding adaptor protein complex 1 subunit $\sigma 1$, a protein that is necessary for the trafficking of ATP7A and ATP7B out of the TGN.

\section{Iron Homeostasis and its Disorders}

Over the last decade, much has been learned about i) hormonal regulation of plasma iron levels and ii) cellular processing of iron regulation and it regulation.

\section{Hormonal Regulation of Plasma Iron Concentration}

An increased plasma iron level leads to increased transcription of hepcidin from HAMP. The increased level of hepcidin in the circulation has major effects on target cells - principally enterocytes and macrophages (Figure 4). In both cell types the action of hepcidin leads to degradation of ferroportin, the main channel for export of iron from the cell. The action on 
enterocytes leads to reduced intestinal absorption of iron. The action on macrophages reduces the release of iron into the plasma from the stores in these cells. The net result is for the plasma iron to be reduced so that it is back in the normal range. If the hepcidin pathway is impaired, iron from plasma will be taken up by cells of the liver, pancreas, heart and other organs leading to cirrhosis, diabetes, cardiomyopathy etc (haemochromatosis). Infection and inflammation can trigger the secretion of hepcidin when plasma iron is normal, leading to the low plasma iron seen in chronic infection / inflammation.

The gene defects that can cause hereditary haemachromatosis are listed in Tables 1 and 2. The commonest types involve reduced synthesis of hepcidin in reponse to iron (by a mechanism that is not fully understood) e.g. HFE1 mutations. Other mechanisms involve mutations in hepcidin (Table 2) or ferroportin (Table 3).

\section{Cellular Processing of Iron and its Regulation}

A simplified scheme of iron uptake and processing by the cell, and its regulation is shown in Figure 5 (based on Barapula et al 2015). Uptake of $\mathrm{Fe}^{2+}$ at the cell surface can occur via the divalent metal transporter encoded by DMT1. This transporter also mediates uptake into the enterocyte. Transferrin-bound $\mathrm{Fe}^{3+}$ binds to the transferrin receptor at the cell surface and the complex is endocytosed. Uptake from the endocytotic vesicle requires conversion of $\mathrm{Fe}^{3+}$ to $\mathrm{Fe}^{2+}$ catalyzed by the endosomal ferrireductase (STEAP3) followed by uptake of the $\mathrm{Fe}^{2+}$ by DMT1. Transport into the mitochondria requires mitoferrin 1 (MFRN1; SLC25A37) and 2 (MFRN2; SLC25A28). Within the mitochondrion iron has two principal fates synthesis of haem and synthesis of iron-sulphur clusters. Some iron can be stored in the mitochondrion as mitochondrial ferritin (MTFT). Cytosolic iron can be incorporated into Fe- 
proteins and FeS proteins and it can be converted via a PCB1-4 dependent pathway to ferritin the main cellular store from which it can subsequently be released in a controlled fashion. Export from the cell is via ferroportin the activity of which is determined by plasma hepcidin as indicated above. Regulation of cellular iron homeostasis involves binding of cytosolic iron to iron-responsive proteins 1 and 2 (IRP1/2) - also known as iron-reponsive element-binding proteins (IREB1/2). These iron-bearing IRPs bind to iron-responsive elements (IREs) in the $5^{\prime}$ or $3^{\prime}$ untranslated regions of messenger RNAs and regulate transcription of the iron-reponsive protein. A defect in the ability of cells to use iron for synthesis of haem leads to an "iron refractory iron deficient anaemia" and often to liver iron overload. Disorders are listed in Table 4.

Defective haem synthesis is, of course, the basis of the porphyrias. Defects of iron sulphur cluster synthesis have been the subject of recent reviews (Ahting et al. 2015; Rahman and Mayr 2016) and have not been included in this update.

\section{Neurodegeneration with Brain Iron Accumulation (NBIA)}

Ten inborn errors lead to NBIA. For two of these the mechanism is understood:

\section{Acaeruloplasminaemia}

Biallelic mutations in $C P$ lead to undetectable levels of caeruloplasmin in plasma. Patients have accumulation of iron in the liver, islets of Langerhans and brain. They present in adult life with neurological symptoms (chorea, ataxia, dystonia, Parkinsonism and psychiatric disorders), retinal degeneration and diabetes mellitus. Caeruloplasmin is a coppercontaining enzyme secreted by the liver into the plasma that converts ferrous $\left(\mathrm{Fe}^{2+}\right)$ iron (which is the form of iron that is taken up from the diet and the form is stored in ferritin) to 
ferric $\left(\mathrm{Fe}^{3+}\right)$ iron (which is the iron species that can be transported in the circulation by transferrin). Patients with acaeruloplasminaemia have a low serum iron (mostly transferrinbound) and a high serum ferritin. This suggests that the excessive uptake of iron into the basal ganglia may be attributable to uptake of ferrous iron which is then stored as ferritin.

Treatment with the iron chelator, desferrioxamine leads to a reduction in body iron stores as well as amelioration of diabetes and a decrease in neurologic symptoms (Miyajima et al. 1997).

\section{Neuroferritinopathy}

Heterozygous mutations in FTL affecting the last part of the light chain of ferritin lead to deposits of iron and ferritin in the brain, particularly the basal ganglia. Patients present in in early adult life with progressive neurological symptoms (chorea, ataxia, rigidity, dystonia, cognitive impairment). Using a mouse model of the disease Garringer et al (2016) showed that treatment of cells with the iron chelator, deferiprone, could decrease the iron content of the cells and increase cell viability. However, in vivo studies failed to improve the CNS pathology.

\section{Metals in Innate Immunity}

Iron

NRAMP1 (SLC11A1) is a transporter of $\mathrm{Fe}^{2+}$ found in membranes of phagocytic vacuoles of macrophages and neutrophils. NRAMP1 mutations in mice impair resistance to intracellular parasites e.g.Salmonella, Leishmania, Mycobacterium (Canonne-Hergauxet al 1999). It is thought that NRAMP1 controls intracellular microbial replication by actively removing $\mathrm{Fe}^{2+} /$ 
other divalent cations from the phagosomal space. In man, meta-analysis confirms an association between SLC11A1 polymorphisms and tuberculosis (Li et al. 2011), supporting the hypothesis that NRAMP1 is important in human defence against TB.

\section{Copper}

Mice respond to infection with Candida albicans by trying to poison the fungus with copper; however the pathogen is also capable of modifying its copper metabolism (Mackie et al 2016).

\section{Conclusion}

Inborn errors of transition metals along with advances in basic science are allowing us to understand much more about the metabolism of these micronutrients and its regulation and this in turn is leading to new treatments. There is, however, still a lot to learn.

\section{Acknowledgments}

I would like to particularly thank the following colleagues for their collaboration on investigation of disorders of manganese homeostasis: Karin Tuschl, Philippa Mills, Steve Wilson, Manju Kurian, Esther Meyer, Kling Chong and the others authors of the Tuschl et al papers.

\section{References}

Ahting U, Mayr JA, Vanlander AV, Hardy SA, Santra S, Makowski C, Alston CL, Zimmermann FA, Abela L, Plecko B, Rohrbach M, Spranger S, Seneca S, Rolinski B, Hagendorff A, Hempel M, Sperl W, Meitinger T, Smet J, Taylor RW, Van Coster R, Freisinger P, Prokisch H, Haack TB. 2015. Clinical, biochemical, and genetic spectrum of seven patients with NFU1 deficiency. Front Genet 6:123. 
Barupala DP, Dzul SP, Riggs-Gelasco PJ, Stemmler TL. 2016. Synthesis, delivery and regulation of eukaryotic heme and Fe-S cluster cofactors. Arch Biochem Biophys. 592:60-75

Boycott KM, Beaulieu CL, Kernohan KD, Gebril OH, Mhanni A, Chudley AE, Redl D, Qin W, Hampson S, Küry S, Tetreault M, Puffenberger EG, Scott JN, Bezieau S, Reis A, Uebe S, Schumacher J, Hegele RA, McLeod DR, Gálvez-Peralta M, Majewski J, Ramaekers VT; Care4Rare Canada Consortium., Nebert DW, Innes AM, Parboosingh JS, Abou Jamra R. 2015. Autosomal-Recessive Intellectual Disability with Cerebellar Atrophy Syndrome Caused by Mutation of the Manganese and Zinc Transporter Gene SLC39A8. Am J Hum Genet. 97(6):886-93.

Canonne-Hergaux F, Gruenheid S, Govoni G, Gros P. 1999. The Nramp1 protein and its role in resistance to infection and macrophage function. Proc Assoc Am Physicians 111(4):283-9.

Chen P, Chakraborty S, Mukhopadhyay S, Lee E, Paoliello MM, Bowman AB, Aschner M. 2015. Manganese homeostasis in the nervous system. J Neurochem. 134(4):601-10.

Chesi G, Hegde RN, lacobacci S, Concilli M, Parashuraman S, Festa BP, Polishchuk EV, Di Tullio G, Carissimo A, Montefusco S, Canetti D, Monti M, Amoresano A, Pucci P, van de Sluis B, Lutsenko S, Luini A, Polishchuk RS. 2016. Identification of p38 MAPK and JNK as new targets for correction of Wilson disease-causing ATP7B mutants. Hepatology 63(6):1842-59.

Chowanadisai W, Lönnerdal B, Kelleher SL. 2006. Identification of a mutation in SLC30A2 (ZnT-2) in women with low milk zinc concentration that results in transient neonatal zinc deficiency. J Biol Chem. 281(51):39699-707.

Członkowska A, Litwin T, Karliński M, Dziezyc K, Chabik G, Czerska M. 2014. D-penicillamine versus zinc sulfate as first-line therapy for Wilson's disease. Eur J Neurol. 21(4):599-606.

Dhawan A, Taylor RM, Cheeseman P, De Silva P, Katsiyiannakis L, Mieli-Vergani G. Wilson's disease in children: 37-year experience and revised King's score for liver transplantation. Liver Transpl. 2005 Apr;11(4):441-8.

Garringer HJ, Irimia JM, Li W, Goodwin CB, Richine B, Acton A, Chan RJ, Peacock M, Muhoberac BB, Ghetti B, Vidal R. 2016. Effect of Systemic Iron Overload and a Chelation Therapy in a Mouse Model of the Neurodegenerative Disease Hereditary Ferritinopathy. PLoS One. 30;11(8):e0161341

IUPAC, Compendium of Chemical Terminology, 2nd ed. (the "Gold Book") (1997). Online corrected version: (2006-) "transition element" http://goldbook.iupac.org/T06456.html

Kambe T, Tsuji T, Hashimoto A, Itsumura N. The Physiological, Biochemical, and Molecular Roles of Zinc Transporters in Zinc Homeostasis and Metabolism. Physiol Rev. 95(3):749-84.

Küry S, Dréno B, Bézieau S, Giraudet S, Kharfi M, Kamoun R, Moisan JP. 2002. Identification of SLC39A4, a gene involved in acrodermatitis enteropathica. Nat Genet. 31(3):239-40.

Li X, Yang Y, Zhou F, Zhang Y, Lu H, Jin Q, Gao L. 2011. SLC11A1 (NRAMP1) polymorphisms and tuberculosis susceptibility: updated systematic review and meta-analysis. PLoS 6(1):e15831. doi: 10.1371/journal.pone.0015831. 
Lichtmannegger J, Leitzinger C, Wimmer R, Schmitt S, Schulz S, Kabiri Y, Eberhagen C, Rieder T, Janik D, Neff F, Straub BK, Schirmacher P, DiSpirito AA, Bandow N, Baral BS, Flatley A, Kremmer E, Denk G, Reiter FP, Hohenester S, Eckardt-Schupp F, Dencher NA, Adamski J, Sauer V, Niemietz C, Schmidt HH, Merle U, Gotthardt DN, Kroemer G, Weiss KH, Zischka H. 2016. Methanobactin reverses acute liver failure in a rat model of Wilson disease. J Clin Invest. 126(7):2721-35.

Litwin T, Dzieżyc K, Karliński M, Chabik G, Czepiel W, Członkowska A. 2015. Early neurological worsening in patients with Wilson's disease. J Neurol Sci. 355(1-2):162-7

Mackie J, Szabo EK, Urgast DS, Ballou E, Childers DS, MacCallum DM, Feldmann J, Brown AJ. 2016. Host-Imposed Copper Poisoning Impacts Fungal Micronutrient Acquisition during Systemic Candida albicans Infections. PLoS One 11(6):e0158683. doi:

10.1371/journal.pone.0158683. eCollection 2016.

Martinelli D1, Dionisi-Vici C. 2014. AP1S1 defect causing MEDNIK syndrome: a new adaptinopathy associated with defective copper metabolism. Ann N Y Acad Sci. 2014;1314:55-63.

Martinelli D, Travaglini L, Drouin CA, Ceballos-Picot I, Rizza T, Bertini E, Carrozzo R, Petrini S, de Lonlay P, El Hachem M, Hubert L, Montpetit A, Torre G, Dionisi-Vici C. 2013. MEDNIK syndrome: a novel defect of copper metabolism treatable by zinc acetate therapy. Brain 136:872-81.

Miyajima H, Takahashi Y, Kamata T, Shimizu H, Sakai N, Gitlin JD. 1997. Use of desferrioxamine in the treatment of aceruloplasminemia. Ann Neurol. 41(3):404-7

Moalem S1, Percy ME, Andrews DF, Kruck TP, Wong S, Dalton AJ, Mehta P, Fedor B, Warren AC. 2000. Are hereditary hemochromatosis mutations involved in Alzheimer disease? Am J Med Genet. 3;93(1):58-66.

Niederau C1, Fischer R, Pürschel A, Stremmel W, Häussinger D, Strohmeyer G. 1996.Longterm survival in patients with hereditary hemochromatosis. Gastroenterology 110(4):110719.

Park JH, Hogrebe M, Grüneberg M, DuChesne I, von der Heiden AL, Reunert J, Schlingmann KP, Boycott KM, Beaulieu CL, Mhanni AA, Innes AM, Hörtnagel K, Biskup S, Gleixner EM, Kurlemann G, Fiedler B, Omran H, Rutsch F, Wada Y, Tsiakas K, Santer R, Nebert DW, Rust S, Marquardt T. 2015. SLC39A8 Deficiency: A Disorder of Manganese Transport and Glycosylation. Am J Hum Genet. 97(6):894-903.

Park J H , Hogrebe M, Grueneberg M, Reunert J, Rust S, Marquardt T. 2016. SLC39A8 deficiency is a novel treatable disorder of manganese metabolism and glycosylation. Jinherit Metab Dis 39 Issue 1 Supplement S54.

Quadri M, Federico A, Zhao T, Breedveld GJ, Battisti C, Delnooz C, Severijnen LA, Di Toro Mammarella L, Mignarri A, Monti L, Sanna A, Lu P, Punzo F, Cossu G, Willemsen R, Rasi F, Oostra BA, van de Warrenburg BP, Bonifati V. 2012. Mutations in SLC30A10 cause 
parkinsonism and dystonia with hypermanganesemia, polycythemia, and chronic liver disease. Am J Hum Genet. 90(3):467-77

Rahman S and Mayr JA. 2016. Disorders of oxidative phosphorylation. In J-M Saudubray et al. (Eds) Inborn Metabolic Diseases.Springer Verlag, Berlin, Heidelberg.

Ramakrishnan B, Ramasamy V, Qasba PK. 2006. Structural snapshots of beta-1,4galactosyltransferase-I along the kinetic pathway.J Mol Biol. Apr 14;357(5):1619-33.

Riley LG, Cowley MJ, Gayevskiy V, Roscioli T, Thorburn DR, Prelog K, Bahlo M, Sue CM, Balasubramaniam S, Christodoulou J. 2016. A SLC39A8 variant causes manganese deficiency, and glycosylation and mitochondrial disorders. J Inherit Metab Dis. 2016. Dec 19. [Epub ahead of print] PMID:27995398

Schlaug G, Hefter H, Engelbrecht V, Kuwert T, Arnold S, Stöcklin G Seitz RJ. 1996. Neurological impairment and recovery in Wislon's disease: evidence from PET and MRI. J Neurol Sci 136:129-139.

Sharma V, Karlin KD, Wikström M. 2013. Computational study of the activated $O(H)$ state in the catalytic mechanism of cytochrome c oxidase. Proc Natl Acad Sci U S A. Oct 15;110(42):16844-9.

Tuschl K, Mills PB, Parsons H, Malone M, Fowler D, Bitner-Glindzicz M, Clayton PT. 2008. Hepatic cirrhosis, dystonia, polycythaemia and hypermanganesaemia--a new metabolic disorder. J Inherit Metab Dis. 31(2):151-63.

Tuschl K, Clayton PT, Gospe SM Jr, Gulab S, Ibrahim S, Singhi P, Aulakh R, Ribeiro RT, Barsottini OG, Zaki MS, Del Rosario ML, Dyack S, Price V, Rideout A, Gordon K, Wevers RA, Chong WK, Mills PB. 2012. Syndrome of hepatic cirrhosis, dystonia, polycythemia, and hypermanganesemia caused by mutations in SLC30A10, a manganese transporter in man. Am J Hum Genet. Mar 9;90(3):457-66.

Tuschl K, Meyer E, Valdivia LE, Zhao N, Dadswell C, Abdul-Sada A, Hung CY, Simpson MA, Chong WK, Jacques TS, Woltjer RL, Eaton S, Gregory A, Sanford L, Kara E, Houlden H, Cuno SM, Prokisch H, Valletta L, Tiranti V, Younis R, Maher ER, Spencer J, Straatman-Iwanowska A, Gissen P, Selim LA, Pintos-Morell G, Coroleu-Lletget W, Mohammad SS, Yoganathan S, Dale RC, Thomas M, Rihel J, Bodamer OA, Enns CA, Hayflick SJ, Clayton PT, Mills PB, Kurian MA, Wilson SW. 2016. Mutations in SLC39A14 disrupt manganese homeostasis and cause childhood-onset parkinsonism-dystonia. Nat Commun. 7:11601.

van Hasselt PM, Clayton P \& Houwen RHJ. 2016. Disorders in the transport of copper, iron, magnesium, manganese, selenium and zinc. In Saudubray JM, Baumgartner MR \& Walter J eds. Inborn Metabolic Diseases. Diagnosis and Treatment $6^{\text {th }}$ Edition Springer,Berlin Heidelberg 2016.

Zecca L, Youdim MB, Riederer P, Connor JR, Crichton RR. 2004.Iron, brain ageing and neurodegenerative disorders. Nat Rev Neurosci. 5(11):863-73 


\begin{tabular}{|c|c|c|c|c|c|c|}
\hline $\begin{array}{l}\text { Metal } \\
\text { Accumulating }\end{array}$ & Disorder & Inheritance & Gene & Function of gene product & $\begin{array}{l}\text { Prominent motor } \\
\text { symptoms }\end{array}$ & $\begin{array}{l}\text { Age at } \\
\text { presentation }\end{array}$ \\
\hline Copper & Wilson's disease & $A R$ & ATP7B & Copper transporter & $\begin{array}{l}\text { Dysarthria, dysphagia, } \\
\text { tremor, dystonic rigidity }\end{array}$ & $10 y-30 y$ \\
\hline Manganese & $\begin{array}{l}\text { Dystonia/Parkinsonism, hypermanganesaemia, } \\
\text { polycythaemia, and chronic liver disease }\end{array}$ & $A R$ & SLC30A10 & Manganese transporter & $\begin{array}{l}\text { Dystonia, cock-walk gait } \\
\text { Parkinsonism }\end{array}$ & $\begin{array}{l}\text { Childhood } \\
\text { Middle age }\end{array}$ \\
\hline Manganese & $\begin{array}{l}\text { Infantile / early childhood onset dystonia with } \\
\text { hypermanganesaemia }\end{array}$ & $A R$ & SLC39A14 & Manganese transporter & $\begin{array}{l}\text { Progressive dystonia and } \\
\text { bulbar dysfunction. }\end{array}$ & $\begin{array}{l}\text { Infancy /early } \\
\text { childhood }\end{array}$ \\
\hline Iron & Acaeruloplasminaemia & $A R$ & $C P$ & Ferroxidase & $\begin{array}{l}\text { Chorea, ataxia, dystonia, } \\
\text { Parkinsonism }\end{array}$ & Adulthood \\
\hline Iron & Neuroferritinopathy & $A D$ & $F T L$ & Iron storage & Chorea, dystonia & Middle age \\
\hline Iron & $\begin{array}{l}\text { Pantothenate kinase associated neurodegeneration } \\
\text { (PKAN) }\end{array}$ & $A R$ & PANK2 & $\begin{array}{l}\text { Pantothenate kinase (COA } \\
\text { synthesis) }\end{array}$ & $\begin{array}{l}\text { Dystonia, rigidity, } \\
\text { choreoathetosis }\end{array}$ & $\begin{array}{l}\text { Early } \\
\text { childhood }\end{array}$ \\
\hline Iron & Coenzyme A synthetase deficiency & $A R$ & COASY & CoA synthesis & $\begin{array}{l}\text { Dystonia, rigidity, } \\
\text { choreoathetosis }\end{array}$ & $\begin{array}{l}\text { Early } \\
\text { childhood }\end{array}$ \\
\hline Iron & Infantile neuroaxonal dystrophy (INAD) & $A R$ & PLA2G6 & Phospholipase & $\begin{array}{l}\text { Motor regression, } \\
\text { hypotonia }\end{array}$ & $\begin{array}{l}\text { Infancy / early } \\
\text { childhood }\end{array}$ \\
\hline Iron & Fatty acid hydroxylase associated neurodegeneration & $A R$ & $\mathrm{FA2H}$ & $\begin{array}{l}\text { Fatty acid 2-hydroxylase } \\
\text { (Synthesis of sphingolipids) }\end{array}$ & $\begin{array}{l}\text { Gait difficulties with } \\
\text { spastic paraparesis and } \\
\text { dysmetria }\end{array}$ & $\begin{array}{l}\text { Early } \\
\text { childhood }\end{array}$ \\
\hline Iron & Mitochondrial protein associated neurodegeneration & $A R$ & C19orf12 & $\begin{array}{l}\text { Mitochondrial magnesium } \\
\text { homeostasis }\end{array}$ & $\begin{array}{l}\text { Spastic paraplegia, } \\
\text { Parkinsonism }\end{array}$ & $\begin{array}{l}\text { Childhood / } \\
\text { adulthood }\end{array}$ \\
\hline Iron & Woodhouse-Sakati syndrome & $A R$ & DCAF17 & Ubiquitinylation & $\begin{array}{l}\text { Developmental delay } \\
\text { Dystonia, dysarthria, } \\
\text { choreoathetosis }\end{array}$ & $\begin{array}{l}\text { Childhood } \\
\text { Adolescence }\end{array}$ \\
\hline Iron & $\begin{array}{l}\text { Static encephalopathy of childhood with } \\
\text { neurodegeration in adulthood (SENDA) } \\
\text { Beta-propeller protein-associated neurodegeneration } \\
\text { (BPAN) }\end{array}$ & $\mathrm{XD}$ & WDR45 & Autophagy & $\begin{array}{l}\text { Global developmental } \\
\text { delay } \\
\text { Parkinsonism and } \\
\text { dementia }\end{array}$ & $\begin{array}{l}\text { Childhood } \\
\text { Early } \\
\text { adulthood }\end{array}$ \\
\hline Iron & Kufor-Rakeb syndrome & $A R$ & ATP13A2 & & $\begin{array}{l}\text { Atypical Parkinsonism } \\
\text { Supranucelar gaze palsy } \\
\text { Spasticity }\end{array}$ & Childhood \\
\hline
\end{tabular}

Table 1. Inborn errors of metabolism leading to accumulation of a transition metal in the basal ganglia and substantia nigra. AR, autosomal recessive; $A D$ autosomal dominant; $X D$, X-linked dominant. 


\begin{tabular}{|c|c|c|c|c|c|c|}
\hline Gene & Inheritance & Protein & $\begin{array}{l}\text { Role in Fe } \\
\text { Metabolism }\end{array}$ & Anaemia & $\begin{array}{l}\text { Haemochromatosis } \\
\text { (Cirrhosis, } \\
\text { diabetes, } \\
\text { cardiomyopathy }\end{array}$ & Treatment \\
\hline HAMP & AR & Hepcidin & $\begin{array}{l}\text { Inhibits iron } \\
\text { release by } \\
\text { ferroportin }\end{array}$ & - & $+\left(3^{\text {rd }}-4^{\text {th }}\right.$ decade $)$ & \\
\hline HFE1 & $\begin{array}{l}\mathrm{AR} \\
2 \text { common } \\
\text { mutations }\end{array}$ & HFE & $\begin{array}{l}\text { ? Fe sensor } \\
\text { Regulates } \\
\text { synthesis of } \\
\text { hepcidin }\end{array}$ & - & $+/-\left(4^{\text {th }}-5^{\text {th }}\right.$ decade $)$ & $\begin{array}{l}\text { Phlebotomy } \\
\text { for ferritin } \\
>1000 \\
\mathrm{ng} / \mathrm{ml}\end{array}$ \\
\hline HJV & $A R$ & Haemojuvelin & $\begin{array}{l}\text { Regulates } \\
\text { synthesis of } \\
\text { hepcidin }\end{array}$ & - & $\begin{array}{l}+\left(2^{\text {nd }}-3^{\text {rd }} \text { decade) }\right. \\
\text { (incl. } \\
\text { hypogonadism) }\end{array}$ & $\begin{array}{l}\text { Phlebotomy } \\
\text { effective if } \\
\text { started } \\
\text { early }\end{array}$ \\
\hline TRF2 & $A R$ & $\begin{array}{l}\text { Transferrin } \\
\text { receptor } 2\end{array}$ & $\begin{array}{l}\text { ? Fe sensor } \\
\text { Regulates } \\
\text { synthesis of } \\
\text { hepcidin }\end{array}$ & - & $+\left(3^{\text {rd }}-5^{\text {th }}\right.$ decade $)$ & Phlebotomy \\
\hline
\end{tabular}

Table 2. Inborn errors of metabolism leading to hepcidin deficiency, and thereby haemochromatosis. Although the exact mechanism by which the hepatocyte senses raised plasma iron and increases transcription of hepcidin is not fully understood it is believed that HFE1, HJV and TRF2 gene products participate in this process. 


\begin{tabular}{|l|l|l|l|l|l|l|}
\hline Gene & Inheritance & Protein & $\begin{array}{l}\text { Role in Fe } \\
\text { Metabolism }\end{array}$ & Anaemia & $\begin{array}{l}\text { Haemochromatosis } \\
\text { (Cirrhosis, diabetes, } \\
\text { cardiomyopathy }\end{array}$ & Treatment \\
\hline SLC4OA1 & AD & $\begin{array}{l}\text { Ferroportin } \\
\text { (Loss of } \\
\text { function) }\end{array}$ & $\begin{array}{l}\text { Export from } \\
\text { cells into } \\
\text { circulation }\end{array}$ & $\begin{array}{l}\text { Mild } \\
\text { microcytic }\end{array}$ & $\begin{array}{l}\text { +/- Iron storage in } \\
\text { macrophages }\end{array}$ & \\
\hline SLC4OA1 & AD & $\begin{array}{l}\text { Ferroportin } \\
\text { (Gain; } \\
\text { hepcidin } \\
\text { resistant) }\end{array}$ & & & + & Phlebotomy \\
\hline
\end{tabular}

Table 3. Effects of loss of function and gain of function (hepcidin resistance) mutations in ferroportin. 


\begin{tabular}{|c|c|c|c|c|c|c|}
\hline Gene & Protein & $\begin{array}{l}\text { Role in Fe } \\
\text { Metabolism }\end{array}$ & $\begin{array}{l}\text { Microcytic } \\
\text { Anaemia }\end{array}$ & $\begin{array}{l}\text { Liver Fe } \\
\text { overload }\end{array}$ & Other & Treatment \\
\hline SLC11A2 & DMT1 & $\begin{array}{l}\text { Duodenal } \\
\text { uptake } \\
\text { Intracellular } \\
\text { release }\end{array}$ & + & + & $\begin{array}{l}\text { Increased Cu in brain } \\
\text { associated with } \\
\text { impulsivity in rat } \\
\text { model }\end{array}$ & $\begin{array}{l}\text { Erythropoietin } \\
\text { (EPO) }\end{array}$ \\
\hline TMPRSS6 & $\begin{array}{l}\text { Matriptase } \\
2\end{array}$ & $\begin{array}{l}\text { Cleavage of } \\
\text { haemojuvelin } \\
\text { Mutations } \\
\text { lead to high } \\
\text { hepcidin } \\
\text { levels }\end{array}$ & $\begin{array}{l}+ \\
\text { IRIDA* }\end{array}$ & + & & $\mathrm{i} / \mathrm{v} \mathrm{Fe}$ \\
\hline STEAP3 & STEAP3 & $\begin{array}{l}\text { Endosomal } \\
\text { ferrireductase } \\
\text { required for } \\
\text { uptake into } \\
\text { cytoplasm } \\
\end{array}$ & + & + & $\begin{array}{l}\text { Hepatosplenomegaly } \\
\text { Hypopituitarism } \\
\text { Hypogonadism }\end{array}$ & $\begin{array}{l}\text { Transfusion } \\
\text { Fe chelation }\end{array}$ \\
\hline TFRC & $\begin{array}{l}\text { Transferrin } \\
\text { receptor } 1\end{array}$ & $\begin{array}{l}\text { Cellular } \\
\text { uptake }\end{array}$ & + & & $\begin{array}{l}\text { Combined } \\
\text { immunodeficiency } \\
\text { Leukopenia } \\
\text { Thrombocytopenia }\end{array}$ & \\
\hline$T F$ & Transferrin & $\begin{array}{l}\text { Fe transport } \\
\text { in blood, } \\
\text { uptake }\end{array}$ & + & + & $\begin{array}{l}\text { Growth retardation } \\
(\mathrm{TF}<20 \mathrm{mg} / \mathrm{dL})\end{array}$ & $\begin{array}{l}\text { Plasma } \\
\text { infusions }\end{array}$ \\
\hline
\end{tabular}

Table 4. Disorders affecting the ability of the cell to take up iron, maintain adequate levels in cytosol and mitochondria and incorporate into haem. 


\begin{tabular}{|c|c|c|c|c|c|c|c|c|c|c|c|c|c|c|c|c|c|}
\hline 1 & & & & & & & & & & & & & & & & & 18 \\
\hline $\mathrm{H}$ & 2 & \multirow{2}{*}{\multicolumn{10}{|c|}{ d-series }} & 13 & 14 & 15 & 16 & 17 & \\
\hline & & & & & & & & & & & & & C & $N$ & 0 & & \\
\hline $\mathrm{Na}$ & $\mathrm{Mg}$ & 3 & 4 & 5 & 6 & 7 & 8 & 9 & 10 & 11 & 12 & & & $P$ & $S$ & $\mathrm{Cl}$ & \\
\hline $\mathrm{K}$ & $\mathrm{Ca}$ & & & & $\mathrm{Cr}$ & $\mathrm{Mn}$ & $\mathrm{Fe}$ & $\mathrm{Co}$ & & $\mathrm{Cu}$ & $\mathrm{Zn}$ & & & & $\mathrm{Se}$ & & \\
\hline & & & & & Mo & & & & & & & & & & & 1 & \\
\hline & & & & & & & & & & & & & & & & & \\
\hline
\end{tabular}

Figure 1. The biological periodic table. Red, major building blocks (96\% mass of organism); green, major minerals; blue and yellow trace elements (micronutrients). The seven trace metals are in groups 3 to 12 of the periodic table (the $d$ series). With the exception of zinc they have an incomplete $d$ sub shell of electrons. 


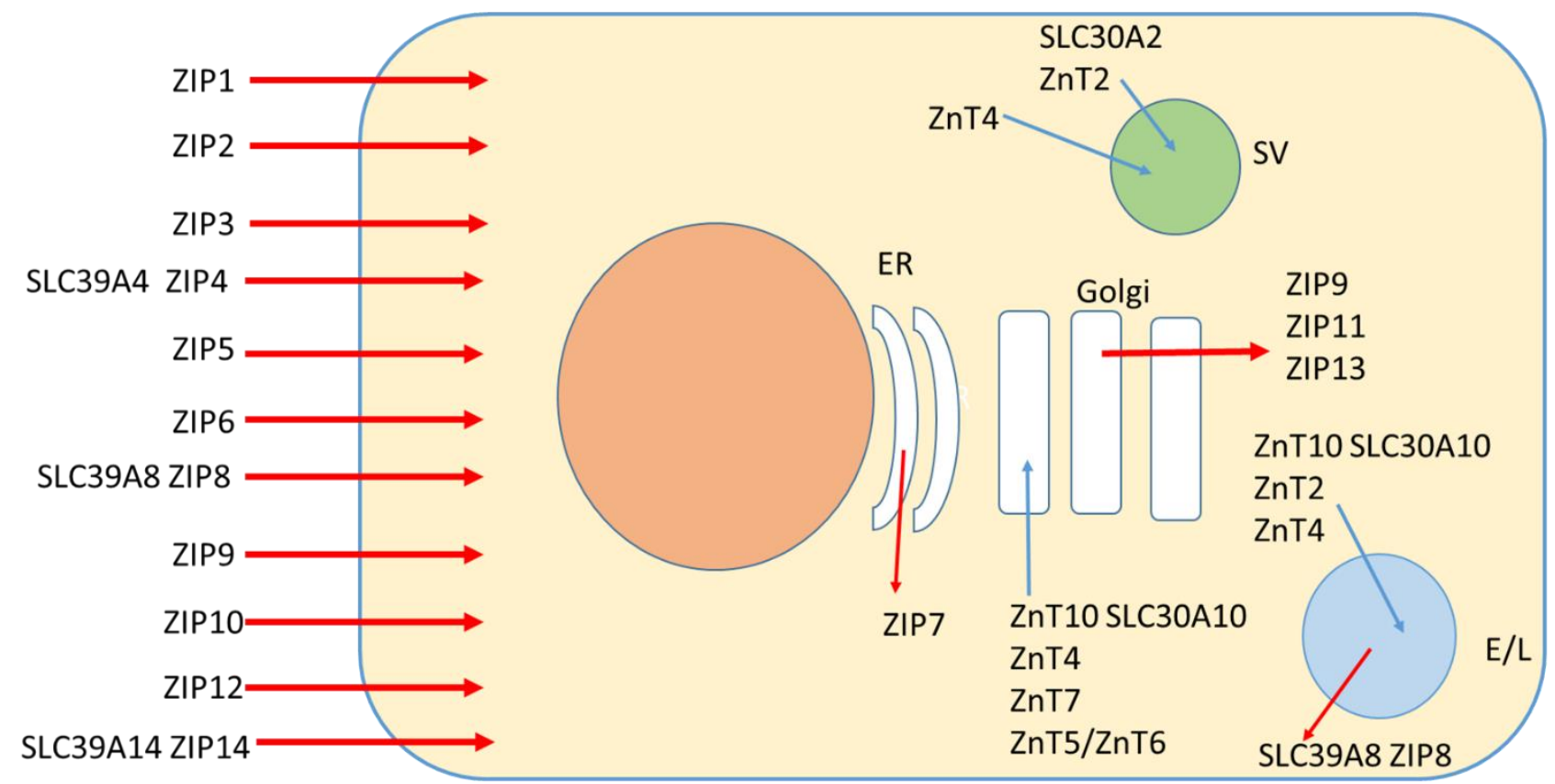

Figure 2. A 2015 view of zinc transporters (simplified from Kambe et al 2015). ZIP transporters are now placed in the SLC39A family; for disorders to be discussed the SLC39A name is given alongside the ZIP name. ZnT transporters are placed in the SLC30A family; for disorders to be discussed the SLC30A name is given alongside the ZnT name. ER, endoplasmic reticulum; SV, (mammary) secretory vesicle; E/L endosome/lysosome. 


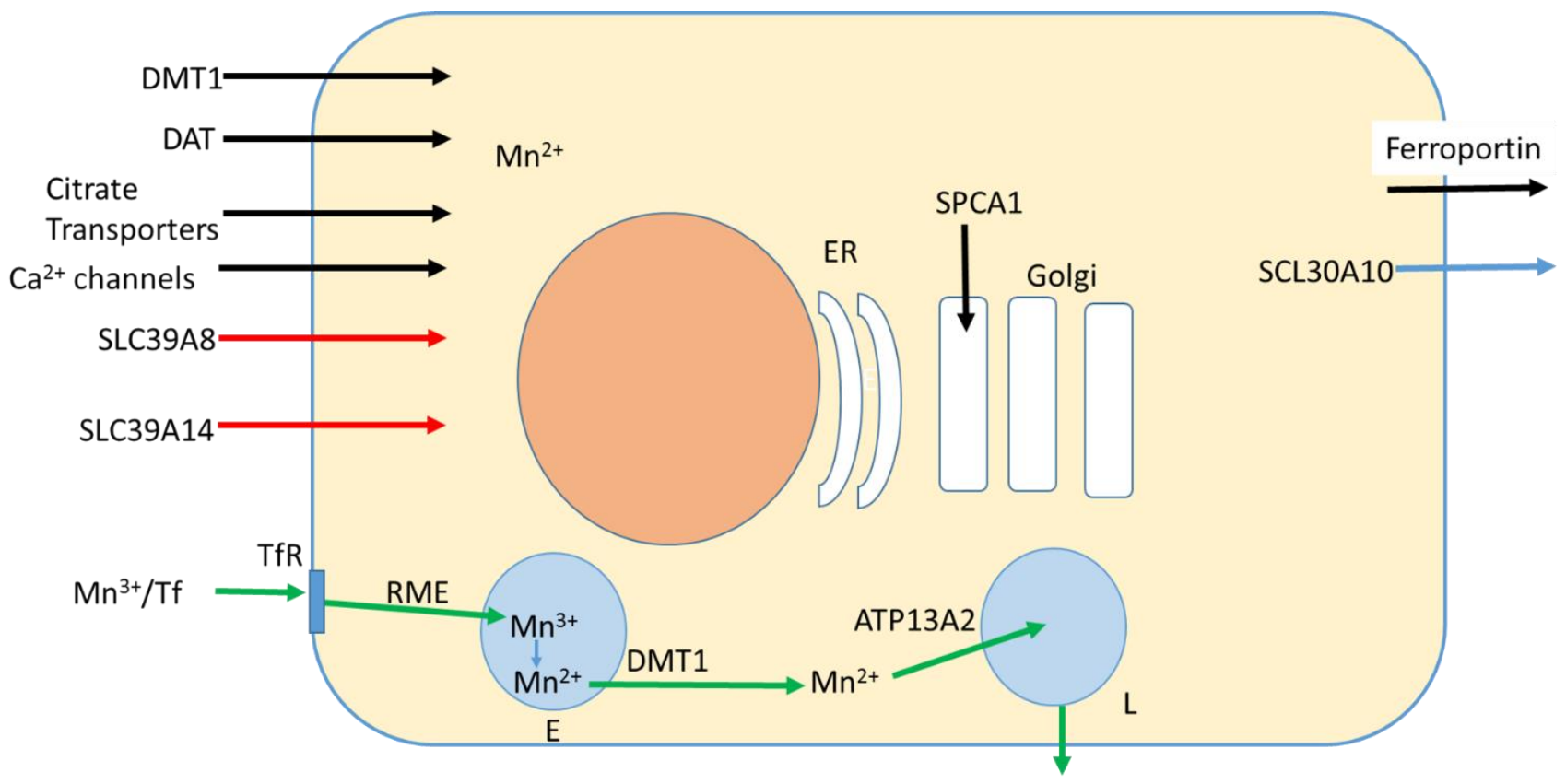

Figure 3. A 2015 view of manganese transporters (simplified from Chen et al 2015). ER, endoplasmic reticulum; $E$, endosome; L, lysosome: RME, receptor-mediated endocytosis; $T f$, transferrin, TfR, transferrin receptor. 
Haemochromatosis

Uptake by liver, pancreas, heart

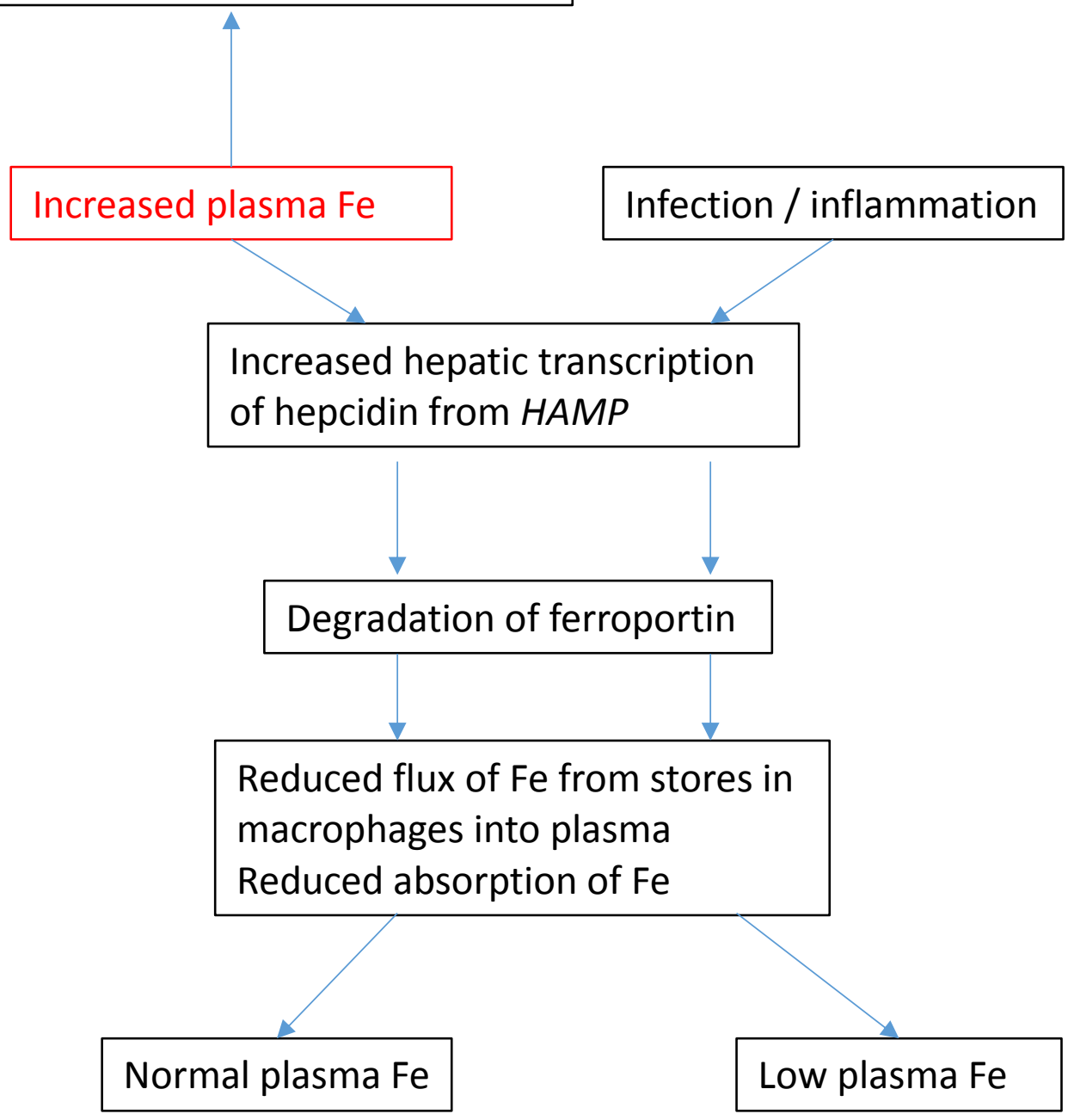

Figure 4. Hormonal control of plasma iron by hepcidin. Failure to activate left-hand pathway in response to a high plasma iron leads to haemochromatosis. Right-hand pathway explains why chronic infection / inflammation leads to a low plasma iron. 


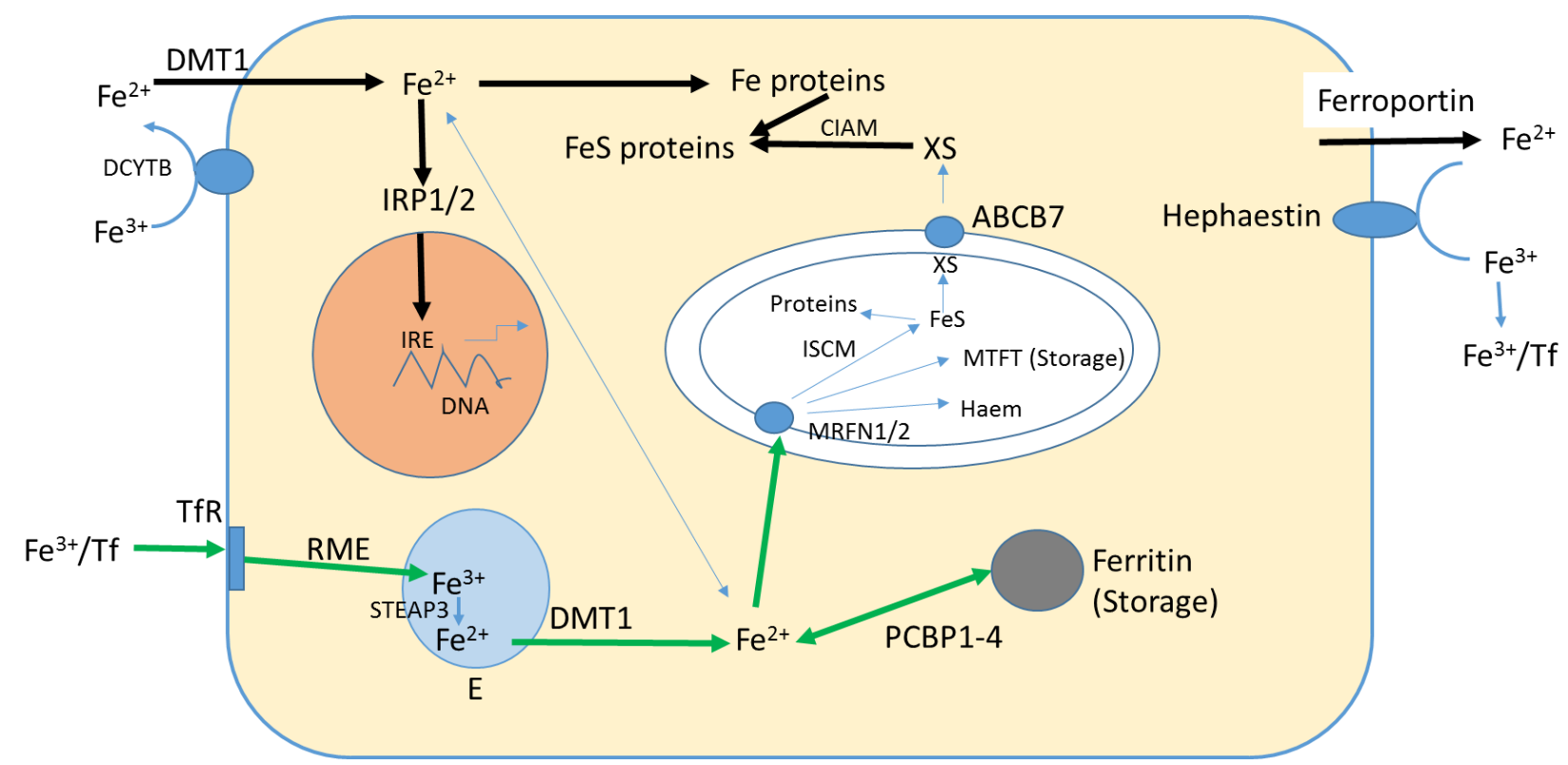

Figure 5. Cellular iron metabolism and its regulation (after Barapula et al 2015). RME, receptor-mediated endocytosis, $\mathrm{E}$, endosome; $\mathrm{Ff}$, transferrin, TfR, transferrin receptor; IRP, iron-reponsive protein, IRE, iron responsive element; FeS, iron sulphur cluster; XS, unknown sulphur transporter; ISCM, iron sulphu cluster machinery; CIAM, cytosolic iron-sulphur cluster assembly machinery; PCBP, poly $(\mathrm{rC})$ binding protein. 
